University of Nebraska - Lincoln

DigitalCommons@University of Nebraska - Lincoln

\title{
Watershed Vulnerability To Herbicide Transport in Northern Missouri and Southern lowa Streams
}

\author{
R. N. Lerch \\ University of Missouri - Columbia \\ P. E. Blanchard \\ University of Missouri - Columbia
}

Follow this and additional works at: https://digitalcommons.unl.edu/usdaarsfacpub

Part of the Agricultural Science Commons

Lerch, R. N. and Blanchard, P. E., "Watershed Vulnerability To Herbicide Transport in Northern Missouri and Southern lowa Streams" (2003). Publications from USDA-ARS / UNL Faculty. 307.

https://digitalcommons.unl.edu/usdaarsfacpub/307

This Article is brought to you for free and open access by the U.S. Department of Agriculture: Agricultural Research Service, Lincoln, Nebraska at DigitalCommons@University of Nebraska - Lincoln. It has been accepted for inclusion in Publications from USDA-ARS / UNL Faculty by an authorized administrator of DigitalCommons@University of Nebraska - Lincoln. 
Watershed Vulnerability To Herbicide Transport in Northern Missouri and Southern lowa Streams

\begin{abstract}
R. N. LERCH*, ${ }^{*}$ AND P. E. BLANCHARD $\neq, \S$ USDA-Agricultural Research Service, Cropping Systems and Water Quality Research Unit, 269 Agricultural Engineering Building, University of Missouri, Columbia, Missouri 65211, and Department of Biological and Agricultural Engineering, University of Missouri, Columbia, Missouri 65211
\end{abstract}

Herbicide contamination of streams has been well documented, but little is currently known about the specific factors affecting watershed vulnerability to herbicide transport. The primary objectives of this study were (1) to document herbicide occurrence and transport from watersheds in the northern M issouri/ southern lowa region; (2) to quantify watershed vulnerability to herbicide transport and relate vulnerability to soil properties; and (3) to compute the contribution of this region to the herbicide load of the Missouri and Mississippi Rivers. Grab samples were collected under baseflow and runoff conditions at 21 hydrologic monitoring stations betw een A pril 15 and J uly 15 from 1996 to 1999. Samples were analyzed for commonly used soil-applied herbicides (atrazine, cyanazine, acetochlor, alachlor, metolachlor, and metribuzin) and four triazine metabolites (deisopropylatrazine, deethylatrazine, hydroxyatrazine, and cyanazine amide). Estimates of herbicide load and relative losses were computed for each watershed. Median parent herbicide losses, as a percentage of applied, ranged from 0.33 to $3.9 \%$; loss rates that were considerably higher than other areas of the United States. Watershed vulnerability to herbicide transport, measured as herbicide load per treated area, showed that the runoff potential of soils was a critical factor affecting herbicide transport. Herbicide transport from these watersheds contributed a disproportionately high amount of the herbicide load to both the M issouri and Mississippi Rivers. Based on these results, this region of the Corn Belt is highly vulnerable to transport of herbicides from fields to streams, and it should be targeted for implementation of management practices designed to reduce herbic ide losses in surface runoff.

\section{Introduction}

Herbicide contamination of streams is one of the major environmental impacts of row crop production. Field runoff represents the primary hydrologic mechanism responsible for herbicide transport from agricultural fields to streams

\footnotetext{
* Correspondingauthor phone: (573)882-9489; fax: (573)882-1115; e-mail: lerchr@missouri.edu.

+ USDA-Agricultural Research Service.

₹ Department of Biological and Agricultural Engineering.

$\S$ Present address: Missouri Department of Conversation, $1110 \mathrm{~S}$. College Ave., Columbia, MO 65201.
}

(1-4). Over the past decade, several studies have overwhelmingly demonstrated that row crop production leads to frequent detections and potentially harmful levels of commonly used corn and soybean herbicides and their metabolites in streamwater $(1,5-11)$.

In the Midwestern United States, maximum herbicide concentrations and frequency of detectionsfollow herbicide application to fields in the spring $(1,5,7,8,12)$. The inopportune coincidence of herbicide application with intense spring rainfall events creates a critical herbicide loss period during the second and third quarters of each year (9, 13). Herbicides that are not persistent in thesoil environment generally show the largest increases in detection frequency between the pre- and postplant periods. For example in the study by Thurman et al. (12), alachlor detections increased from $18 \%$ at preplant to $86 \%$ at postplant. Atrazine, which is more persistent than the acetanilide herbicides $(14,15)$, typically shows detection frequencies greater than $90 \%$ during pre and postplant periods. However, median atrazine concentrations were 9-17 times greater at postplant compared to preplant in two regional-scale studies $(1,12)$.

There are many factors affecting herbicide transport to streams, and they can be organized into four general categories: (1) intrinsic factors - soil and hydrologic properties and geomorphologic characteristics of the watershed; (2) anthropogenic factors - land-use and herbicide management; (3) climatefactors - particularly precipitation and temperature; and (4) herbicide factors - chemical and physical properties and formulation (1-4). A central issue in the herbicide transport literature has been the relative importance of intrinsic versus anthropogenic factors. Landuse within a watershed, as measured by the type and areal extent of row-crops, determines the herbicide inputs to a watershed. Larson and Gilliom (16) reported that herbicide use intensity within a watershed was the most significant factor for predicting herbicide concentrations in streams, and none of the intrinsic factors considered, when taken individually, explained a higher proportion of the variability than herbicide use intensity. However, Blanchard and Lerch (1) reported that land-use was a less important factor to herbicide transport than soil characteristics, hydrology, and herbicide chemical properties. In northern Missouri and southern lowa (the same area presented in this study), watersheds with the highest corn acreage, and therefore greatest herbicide input, had lower atrazine and cyanazine stream concentrations during the critical loss period than watersheds with less than half as much corn acreage. Richards et al. (9) also observed that soil characteristics, and their impact on watershed hydrology, were moreimportant factors controlling herbicide transport than land-use in three watersheds of the Lake Erie basin.

One of the most important intrinsic watershed characteristics affecting herbicide transport is the runoff potential of its soils, which is primarily determined by soil particle size distribution (i.e., soil texture) and topography (1-3). Hydrologic soil group (HSG) categories represent one way to rank runoff potential of soils, and they have been shown to be valid indicators of regional hydrology and watershed vulnerability to herbicidetransport (1). Battaglin and Goolsby (17) reported that hydrologic soil groups was a significant factor in 17 of 36 regression models used to predict herbicide concentrations in reservoir outflows. The positive sign for HSG in these models indicated that higher herbicide concentrations in reservoirs were associated with basins having poorly drained or clay-rich soils (17). Soil texture directly affects water infiltration rate, and, therefore, it largely 


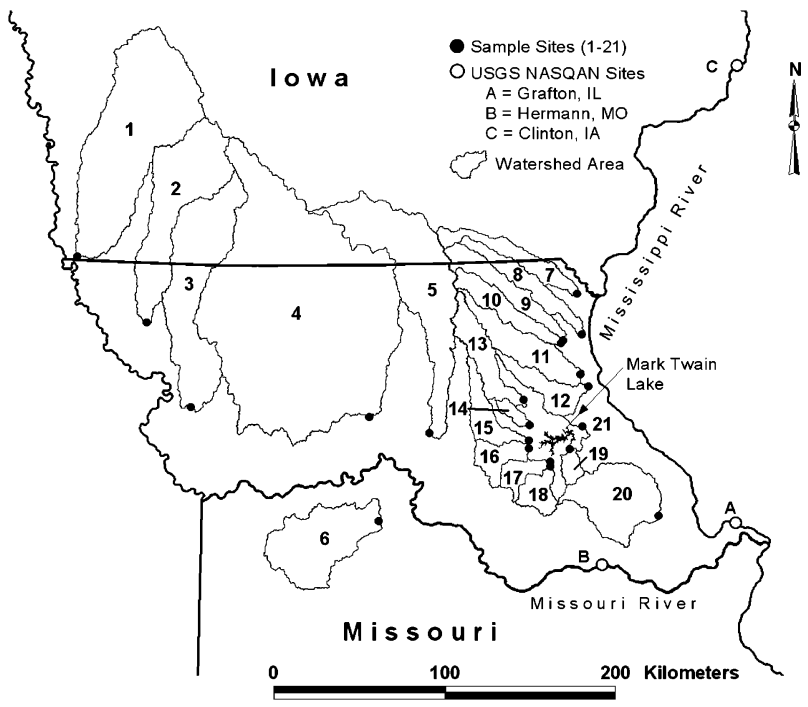

FIGURE 1. Watersheds of northern Missouri and southern lowa included in the study. Entire area encompasses approximately 56700 $\mathbf{k m}^{2}$. See Table 1 for reference list of $w$ atershed names.

determines the dominant hydrologic pathway of the watershed. Watersheds dominated by clayey soils, or those with prominent argillic horizons, will typically havelow infiltration rates and high surface runoff volume and will be vulnerable to surfacetransport of herbicides (1). Those watersheds with a predominance of silty or sandy soils will have high infiltration and percolation rates, low surface runoff volume, low vulnerability to surface transport of herbicides, but high vulnerability to nitrate leaching (1). Particle size and organic matter content of soils will also influence transport by affecting the extent of herbicide sorption.

Two other important factors are the chemical properties of the herbicide and the application method. The chemical structure will determineenvi ronmentally relevant properties such as water solubility, acid/ base dissociation constants, soil sorption intensity, volatility, and persistence. Soil sorption intensity, along with soil texture, will determinethe potential hydrologic loss pathways (1) and the partitioning of herbicide between solution and sorbed phases in field runoff (18). Other herbicide chemical properties, such as persistence in soils and volatilization, will affect the mass of parent compound and metabolites available for transport. Numerous field and stream monitoringstudies have shown that herbicideloss in runoff was significantly greater for surface applied compared to soil incorporated herbicides $(2,4)$.

Theinfluence of land-use and climatearescale dependent (2). At the field or small watershed scales ( $<10000 \mathrm{ha}$ ), the timing of rainfall relativeto herbicideapplication isthesingle most important factor controlling year-to-year variability in transport $(2,9)$. As scale increases, the application period is broadened spatially and temporally, leading to decreased year-to-year variability in transport. Thus, at intermediate and largescales ( $>10000 \mathrm{ha}$ ), the timing of individual storms becomes less important and total precipitation during the critical loss period, which directly affects stream discharge, becomes more important (13). The effect of land-use on herbicide concentrations in streams is also very scale dependent. Herbicide concentrations in runoff will tend to decrease with increasing scale because of dilution from untreated land areas $(1,3-5,7,12)$.

Studies conducted by the U.S. Geological Survey (USGS) National Stream Quality Accounting Network (NASQAN) have been used to estimate the herbicide load of the largest subbasins to the Mississippi River (13). Their results indicated that the Missouri River at Herman, MO (site B, Figure 1) contributed from 25 to $58 \%$ of thecorn and soybean herbicide load to the Mississippi River at Thebes, IL (just above the confluence with the Ohio River). In addition, thearea between Clinton, I A (Figure 1) and Thebes, IL contributed 34-69\% of the load to the Mississippi River at Thebes. Whilethe NASQAN data has provided useful information about herbicide transport in the largest sub-basins of the Mississippi River, there remains agap in our knowledge regardingthe herbicide contribution of smaller sub-basins within the Missouri and Mississippi Rivers. This information would contribute to a more detailed understanding of which areas transport the greatest herbicide load to the large river systems, and it will provide a basis for prioritizing implementation of best management practices (BMPs) to the most vulnerable watersheds. The primary objectives of this study were (1) to document herbicide occurrence (i.e., concentrations and frequency of detection) and to estimate herbicide transport from 21 watersheds encompassing the northern Missouri/ southern lowa region (Figure 1); (2) to quantify watershed vulnerability to herbicide transport and relate vulnerability to soil properties; and (3) to compute the contribution of this region to the herbicide load of the Missouri and Mississippi Rivers.

\section{Methods}

Stream Sampling. The study area included 21 sites, 20 streams, and 1 reservoir outlet, drainingapproximately 56700 $\mathrm{km}^{2}$ in northern Missouri and southern lowa (Figure 1 and Table 1). Stream samples represented watershed areas ranging from 21276 to 1796154 ha, with a median area of 115500 ha (Table 1). Grab samples were collected at USGS hydrologic monitoringstations (Figure 1 and Table 1) between April 15 and July 15 from 1996 to 1999. Sampleswere collected under baseflow and runoff conditions. A single sample was collected from the main flow paths for the smallest streams, and for the larger streams, subsamples were collected at two or three locations in a transect across the stream. All samples weretransported to the laboratory on ice and filtered through $0.45 \mu \mathrm{m}$ nylon filters, typically within $48 \mathrm{~h}$, but never more than $72 \mathrm{~h}$, of collection. For thelarger streams, all subsamples were mixed to create a single composite sample just before filtration. The fewest number of samples collected at any site was five and the most was 11 , with an average of eight samples per site per year. In general, samples were equally distributed between baseflow and runoff conditions in order to discern changes in herbicideconcentrations with changing stream discharge. However, prolonged runoff or baseflow conditionsfor somesites and years precluded equal sampling distribution, but the rarer of the two discharge conditions was always sampled. Only seven sites were sampled in 1996 (Table 1), and data from these sites were only used for computing annual herbicide loss as a percent of applied.

Chemical Analyses. Samples were analyzed for the following commonly used corn and soybean herbicides and selected triazine metabolites: acetochlor [2-chloro- $\mathrm{N}$ (ethoxymethyl)-N-(2-ethyl-6-methylphenyl)acetamide]; alachlor [2-chloro- $\mathrm{N}$-(2,6-diethylphenyl)- $\mathrm{N}$-(methoxy-methyl)acetamide]; atrazine [6-chloro- $\mathrm{N}^{2}$-ethyl- $\mathrm{N}^{4}$-(1-methylethyl)1,3,5-triazine-2,4-diamine]; cyanazine [2-((4-chloro-6(ethylamino)-1,3,5-triazin-2-yl)amino)-2-methylpropanenitrile]; cyanazine amide [2-((4-chloro-6-(ethylamino)-1,3,5triazin-2-yl)amino)-2-methylpropylamide, (CYAM)]; deethylatrazine [6-chloro- $\mathrm{N}^{4}$-(1-methylethyl)-1,3,5-triazine-2,4diamine, (DEA)]; deisopropylatrazine [6-chloro- $\mathrm{N}^{2}$-ethyl1,3,5-triazine-2,4-diamine, (DIA)]; hydroxyatrazine [6-hydroxy$\mathrm{N}^{2}$-ethyl-N4-(1-methylethyl)-1,3,5-triazine-2,4-diamine, (HA)]; metolachlor [2-chloro- $\mathrm{N}$-(2-ethyl-6-methylphenyl)- $\mathrm{N}$-(2methoxy-1-methylethyl)acetamide]; and metribuzin [4-amino6-(1,1-dimethylethyl)-3-(methylthio)-1,2,4-triazin-5(4H)one]. Analyses of samples collected in 1996 and 1997 were previously described $(5,7,8)$. For all analytes, terbutylazine 
TABLE 1. Sampled Watersheds, Watershed Drainage Areas, and Relative Area of Pertinent Row Crops

\section{w atershed}

Nishnabotna River

Nodaway River

Platte River

Grand River

Chariton River

Blackwater River

Fox River

Wyaconda River

North Fabius River

Middle Fabius River

South Fabius River

North River

North Fork Salt Riverc

Crooked Creek ${ }^{c}$

Middle Fork Salt Riverc

Elk Fork Salt River ${ }^{c}$

Long Branch Creek ${ }^{c}$

South Fork Salt River ${ }^{c}$

Lick Creek ${ }^{c}$

Cuivre River

Salt River ${ }^{d}$

$\begin{array}{cc}\text { site number } & \text { years sampled } \\ 1 & 1997-1999 \\ 2 & 1997-1999 \\ 3 & 1997-1999 \\ 4 & 1997-1999 \\ 5 & 1997-1999 \\ 6 & 1997-1999 \\ 7 & 1997-1999 \\ 8 & 1997-1999 \\ 9 & 1997-1999 \\ 10 & 1997-1999 \\ 11 & 1996-1999 \\ 12 & 1996-1999 \\ 13 & 1996-1999 \\ 14 & 1996-1999 \\ 15 & 1996-1999 \\ 16 & 1997-1999 \\ 17 & 1997-1999 \\ 18 & 1996-1999 \\ 19 & 1996-1999 \\ 20 & 1997-1999 \\ 21 & 1997-1999\end{array}$

row crop intensity (\% of w atershed area)

$\begin{array}{cccc}\text { soybeans }^{b} & \text { corn } & \text { sorghum } & \text { total } \\ 37.0 & 39.8 & 0.0 & 76.8 \\ 28.7 & 28.3 & 0.0 & 57.0 \\ 28.4 & 22.8 & 0.0 & 51.2 \\ 19.8 & 10.0 & 0.3 & 30.1 \\ 13.4 & 8.6 & 0.1 & 22.1 \\ 20.3 & 13.1 & 1.0 & 34.4 \\ 15.9 & 12.9 & 0.1 & 28.9 \\ 21.4 & 15.8 & 0.1 & 37.3 \\ 18.7 & 12.0 & 0.0 & 30.7 \\ 14.6 & 8.0 & 0.0 & 22.6 \\ 21.2 & 11.6 & 0.1 & 32.9 \\ 22.3 & 12.1 & 1.0 & 35.4 \\ 23.6 & 8.8 & 0.6 & 33.0 \\ 31.0 & 12.7 & 3.5 & 47.2 \\ 22.7 & 7.9 & 1.5 & 32.1 \\ 29.2 & 12.2 & 3.7 & 45.1 \\ 37.0 & 16.3 & 5.9 & 59.2 \\ 28.4 & 12.8 & 5.2 & 46.4 \\ 42.5 & 19.5 & 7.0 & 69.0 \\ 28.5 & 19.2 & 2.5 & 50.2 \\ \mathrm{NA}^{e} & \mathrm{NA} & \mathrm{NA}^{e} & \mathrm{NA}^{e}\end{array}$

${ }^{a}$ MLRA = major land resource area: 107, lowa and Missouri Deep Loess Hills; 108, Illinois and lowa Deep Loess and Drift; 109, lowa and Missouri Heavy Till Plain; 112, Cherokee Prairies; 113, Central Claypan Areas; and 115, Central Mississippi Valley Wooded Slopes. Only the predominant MLRAs are shown for each watershed. ${ }^{b}$ Average crop percentages from 1997 to $1999 .{ }^{c}$ Sub-basins of the Salt River. ${ }^{d}$ Salt River site was only used for computing herbicide load to Mississippi River. e NA = not applicable.

was added as a surrogate to $100 \mathrm{~mL}$ samples which were then concentrated using $500 \mathrm{mg} \mathrm{C}_{18}$ solid-phase extraction (SPE) cartridges (Varian, Harbor City, CA). SPE cartridges were eluted with ethyl acetate followed by gas chromatography (GC) with $\mathrm{N}-\mathrm{P}$ detection or eluted with methanol followed by high performanceliquid chromatography (HPLC) with UV detection. Only HA, cyanazine, and CYAM were analyzed by HPLC. Both methods were validated using GCor HPLC-mass spectrometry (MS) $(5,7)$.

Beginning in 1998, GC/MS replaced the GC/N-P, and theSPE procedure was also modified. As part of implementing this new method, cyanazine was included with the GC/MS analysis. Surrogate (terbutylazine) spiked $200 \mathrm{~mL}$ samples were concentrated using 500 mg C $_{18}$ SPE cartridges, eluted with ethyl acetate, and evaporated to about $0.2 \mathrm{~mL}$ under a stream of ultrapure $\mathrm{N}_{2}$ in a $30^{\circ} \mathrm{C}$ water bath. Phenanthrene$\mathrm{d}_{10}$ was added as an internal standard. The new GC was a Varian 3400 with a Saturn 2000 ion-trap MS detector (Varian, Harbor City, CA). An HP-1 (Agilent Technologies, Palo Alto, CA) capillary fused-silica column $(0.33 \mu \mathrm{m}$ film thickness; 12 $\mathrm{m} \times 0.2 \mathrm{~mm}$ i.d.) was used with Heas the carrier gas at a flow rate of $1 \mathrm{~mL} / \mathrm{min}$ to separate the analytes. A split/splitless injector was used in splitless mode with an injector temperature of $200^{\circ} \mathrm{C}$ and an injection volume of $1 \mu \mathrm{L}$. A multistep temperature program with a total run time of 27 min was used to separate the analytes. MS conditions were as follows: transfer linetemperature, $200^{\circ} \mathrm{C}$; trap temperature, $250^{\circ} \mathrm{C}$; electron impact energy, $70 \mathrm{eV}$; electron multiplier voltage, $-2000 \mathrm{~V}$; and mass scan range, 126-286. The MS was operated in selected ion storage (SIS) mode for quantitation and in full scan modeto confirm compound identity. SIS ions $(\mathrm{m} / \mathrm{z})$ used for quantitation were as follows: DIA, 158; DEA, 172; atrazine, 200; terbutylazine, 214; cyanazine, 212; metribuzin, 198; acetochlor, $146+162+174$; alachlor, 160; and metolachlor, $162+238$. The implementation of theseanalytical procedures in 1998 improved detection limits by $4-145$ times that of the previous method (Table 2 ).

Load Calculations. Herbicide loads for all sampled watersheds, and the NASQAN sites, were computed on a daily basis for the critical loss period of April 15 to June 30 of each year. Thistimeinterval waschosen based on previous work showing that this is the critical loss period for surface transport of herbicides $(3,7,9,12,19)$. Herbicide concentrations for nonsampled days were estimated by linear interpolation between measured concentrations $(13,20)$. The use of linear interpolation for estimating herbicide loads is justified because a consistent relationship between herbicide concentration and stream discharge does not hold for the entirecritical loss period. This relationship will varyaccording to the timing of runoff events relativeto herbicideapplication (20). Boundary conditions also had to be assumed for extrapolating herbicideconcentrations to the beginning and ending of the critical loss period. All herbicideand metabolite concentrations were assumed to be zero on April 1 and July 31. Previous studies indicate that this is a conservative assumption for the triazine herbicidesand their metabolites, but it is a reasonable assumption for the other herbicides $(1,8,11)$. For all sites and years, no samples were collected before April 15; thus, estimated herbicide concentrations at the beginning of the critical loss period were determined by extrapolation from zero concentration on April 1 to the measured concentration of the first sample day. In a correspondingway, ending concentrationswereextrapolated to zero on July 31 for those sites in which no samples were collected after June 30. Measured or estimated concentrations were multiplied by the average daily stream discharge to estimate daily load. NASQAN concentration and discharge data were acquired from the USGS (21). Since the NASQAN project performs year-round monitoring, no assumptions were required with respect to beginning or ending concentrations. For herbicide concentrations that were below the detection limit of the NASQAN analytical methods, a herbicide concentration of one-tenth the detection limit was used to estimate load (13). This assumption is justified in light of the tremendous dilution in herbicide concentrations that may occur within the large river systems, particularly for some of the lower usage herbicides.

In 1998, a discrepancy in the metribuzin loads occurred such that our computed loads were erroneously high, accounting for $>100 \%$ of the metribuzin load in the Missouri and Mississippi Rivers. Since the discharge data are based on the same rating curves from year to year, the two most 
TABLE 2. Detection Limits and Frequency of Detection for Herbicides and Metabolites Evaluateda

\begin{tabular}{ll}
\multicolumn{1}{c}{ herbicide } & detection limit $(\boldsymbol{\mu} \mathbf{g} / \mathbf{L})$ \\
atrazine & $0.04(1996-1997)$ \\
& $0.003(1998-1999)$ \\
deethylatrazine(DEA) & $0.05(1996-1997)$ \\
& $0.004(1998-1999)$ \\
deisopropylatrazine (DIA) & $0.05(1996-1997)$ \\
hydroxyatrazine (HA) & $0.008(1998-1999)$ \\
cyanazine & $0.05(1996-1999)$ \\
& $0.04(1996-1997)$ \\
cyanazine amide (CYAM) & $0.009(1998-1999)$ \\
acetochlor & $0.02(1996-1999)$ \\
& $0.23(1996-1997)$ \\
alachlor & $0.006(1998-1999)$ \\
metolachlor & $0.23(1996-1997)$ \\
metribuzin & $0.003(1998-1999)$ \\
& $0.29(1996-1997)$ \\
& $0.002(1998-1999)$ \\
& $0.10(1996-1997)$ \\
& $0.008(1998-1999)$
\end{tabular}

\begin{tabular}{ccc}
\multicolumn{3}{c}{ frequency of detection (\%) } \\
\hline $1997^{b}$ & 1998 & 1999 \\
100 & 100 & 100 \\
96.3 & 98.8 & 99.5 \\
95.1 & 97.6 & 91.0 \\
98.8 & 100 & 98.6 \\
97.6 & 97.0 & 71.6 \\
95.1 & 92.2 & 67.1 \\
38.0 & 93.4 & 87.2 \\
26.4 & 92.2 & 91.9 \\
85.3 & 99.4 & 99.5 \\
41.1 & 88.0 & 85.8
\end{tabular}

${ }^{a}$ Number in parentheses indicate year(s) for which detection limit applies. ${ }^{b} n=163$ for 1997; $n=166$ for 1998; and $n=211$ for 1999 .

likely possibilities for the discrepancy were an underestimation in metribuzin concentration for the NASQAN data or an overestimation in metribuzin concentrations for our data. Both laboratories utilized a quality assurance program to ensure high quality data, and dilution from high discharge at the NASQAN sites was not an apparent factor. Without an obvious source of error, we elected to omit the metribuzin loads for 1998.

Land and Herbicide Use Estimates. Land use was based on land cover data produced from $30 \mathrm{~m}$ resolution LandSat Thematic Mapper spectral data. The Missouri data were developed by Missouri Resource Assessment Partnership (http:// msdis.missouri.edu/ lulc.html). The lowa data arepart of theNational Land Cover Data and were developed by the Multi-Resolution Land Cover Consortium (http:// www.epa.gov/ mrlc/ nlcd.html). Both thelowa and the M issouri data sets were developed using nominal 1992 data. The lowa land cover categories of row cropsand small grains were combined to bethe equivalent of the Missouri category of row and close grown crops. This category does not provide information on thespecific crops that were grown. Therefore, planted acreage of specific crops was estimated by combining the land cover data with I owa and Missouri county level row crop data (22).

The county level data included the planted area of corn, soybeans, sorghum, wheat, and oats in each county for each year. From these data, two proportions were calculated: (1) total row crop area as a percentage of the total county area and (2) specific crop area as a percentage of total row crop area. The digitized watersheds were then overlaid on a map of the counties within the study area in order to determine the area of each county comprising a given watershed. By multiplying these three proportions together and summing across each county within a watershed, the area of corn, soybeans, and sorghum was computed for each watershed. The key assumption in this approach is that the distribution of row crops was uniform within a county. Existing LandSat data do not yet allow for delineation of the actual spatial distribution of specific row crops.

The suite of herbicides analyzed in this study pertained only to corn, soybeans, and sorghum. Therefore, herbicide use estimates were computed for each watershed by using the estimated area of these crops within each watershed combined with state level annual reports of agricultural chemical usage. For corn and soybeans, herbicide usage data

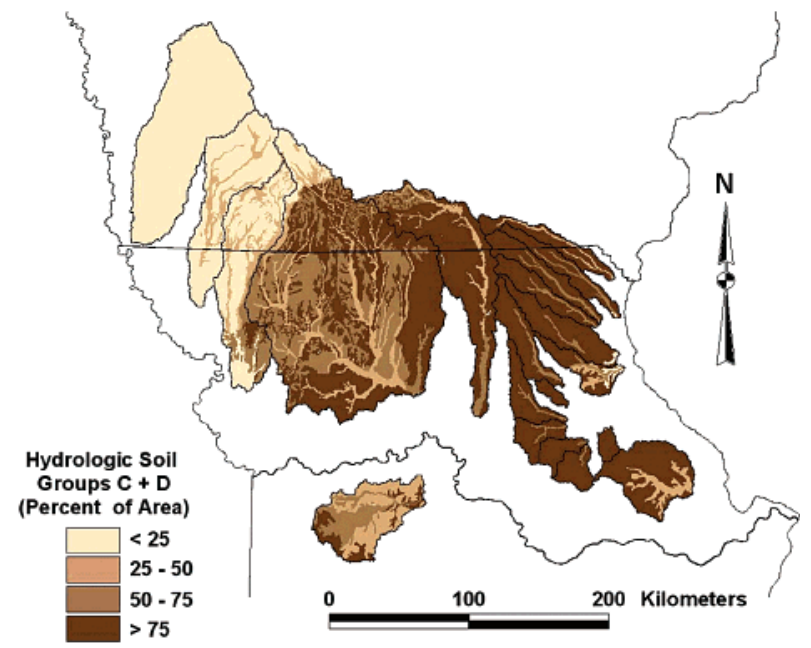

FIGURE 2. Percentage of watershed area within hydrologic soil groups $C$ and $D$.

wereobtained from the USDA-National Agricultural Statistics Service (NASS) (23-26), and for sorghum, usage data were obtained from a 1997 survey conducted by the University of Missouri and USDA National Pesticide Impact Assessment Program (unpublished). Thesereports includethe percentage of crop acres treated by a given herbicide, and its average annual use ratefor each state. For watersheds thatencompass area within lowa and Missouri, treated acreage and use rates for each statewereapplied to their corresponding areas within the watershed. In the 1998 report, metribuzin usage was not reported for soybeans in Missouri, yet it was applied to $14 \%$ and 15\% of the soybeans in 1997 and 1999, respectively. The reported use rate for metribuzin was $0.3 \mathrm{~kg} / \mathrm{ha}$ in 1997 and 1999. Therefore, estimated metribuzin usage for 1998 was based on the average treated acres for 1997 and 1999 (i.e., $14.5 \%$ ) and a use rate of $0.3 \mathrm{~kg} / \mathrm{ha}$. This assumption was justified by the high detection frequency and concentrations of metribuzin in thestreams during 1998 (Table 2 and Figure 4).

\section{Results and Discussion}

Study Area Characteristics. Land-use within the study area is predominantly agricultural, with an average of $96 \%$ of the 


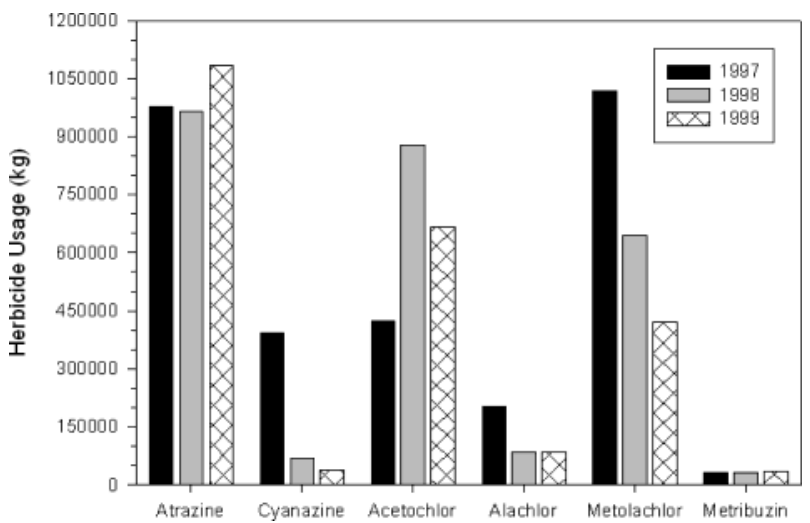

FIGURE 3. Estimated total herbicide usage within the study area from 1997 to 1999.

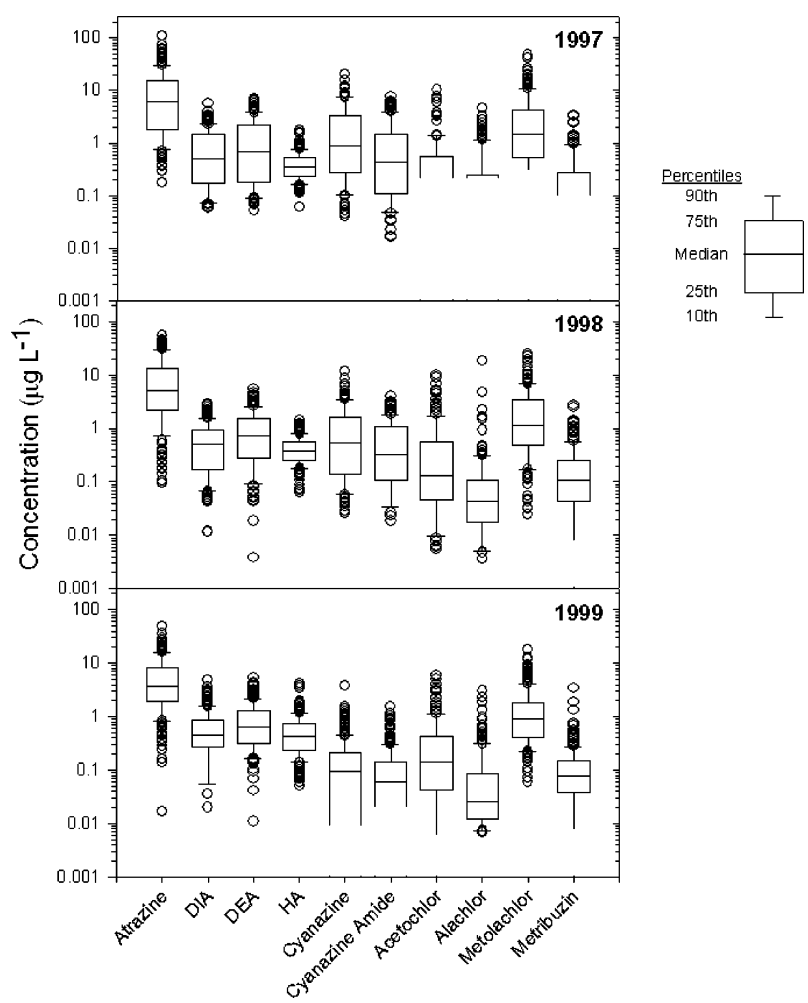

FIGURE 4. Herbicide and herbicide metabolite concentrations, 19971999. B ox plots truncated at detection limits.

watershed areas in row crop or forage production. Corn and soybeans account for about $80 \%$ of the row crop production, with wheat, sorghum, and oats accounting for the remainder of the cropped acreage. Sorghum is a significant crop only in the eastern portion of thestudy area within M issouri (Table 1). Row cropping intensity ranged from 22.1 to $76.8 \%$ of the watershed area (Table 1). In general, row cropping intensity is high in thewestern watersheds (sites 1-3), low in the central watersheds (sites 4-6), and intermediate in the eastern watersheds. However, the eastern portion of the study area varies greatly in land-use, with watersheds of very high cropping intensity (sites 17, 19, and 20) and other watersheds with low cropping intensity (sites 7 and 10).

The HSG represent four general soil categories (A-D), with HSGA having the lowest and HSGD the highest runoff potential. Sincerunoff potential is critical to surface transport of herbicides, it follows that watersheds dominated by HSGC and $\mathrm{D}$ would be the most vulnerable to herbicide transport and subsequent stream contamination. The HSG also closely correspond to the Major Land Resource Area (MLRA) designations within the region $(1,27)$ (Table 1). Within the study area, the runoff potential of soils increases from west to east (Figure 2 ). Sites $1-3$ represent watersheds with low runoff potential soils mainly within HSGA or B. Sites 4-6 represent a transition in which the soils become progressively higher in runoff potential from west to east. Upland and terracesoils within these watersheds are generally designated as HSGC or D, while flood plain soils are mainly HSGB. Sites 7-21 represent watersheds with the highest proportion of soils within the HSGC and D categories. These watersheds have $>75 \%$ of their area within the two highest runoff potential categories. Despite extensive areas with poorly drained soils, tile drainage is rarewithin thestudy area. Dualcode HSG categories indicative of tile drained areas (e.g., HSGA-C or HSGA-D) were not denoted in the STATSGO data for any portion of the watersheds within the study area.

Herbicide Usage of the six herbicides investigated, atrazine, acetochlor, and metolachlor were the most heavily used within the study area (Figure 3). For four of the six herbicides, annual usage within the study area varied considerably over the 3-year period (Figure 3). Cyanazine usage declined 10-fold from 1997 to 1999 as a result of its voluntary phase-out. Cyanazine usage was likely underestimated for 1998 (see below) based on the reported low percentage of corn acreage treated (3\%) and a lower application ratethan was reported for previous or subsequent years (24-26). Estimated acetochlor usage also varied considerably, from 423000 kg in 1997 to 878000 kg in 1998. Theestimated acetochlor usagefor 1998 was largely a function of the high treated acreagein both states and high application rates for M issouri. Alachlor usage decreased from $202000 \mathrm{~kg}$ in 1997 to about $85000 \mathrm{~kg}$ in 1998 and 1999. Alachlor usage has been steadily declining in the Midwestern United States over the past decade (10). Metolachlor usage decreased by nearly $60 \%$ over the study as a result of its declining use and the introduction of the S-metolachlor formulation in 1999. Atrazine usage was consistent during the study, and other than metolachlor in 1997, it was the most heavily used herbicide within thestudy area, with about $1000000 \mathrm{~kg}$ used each year. Corn acreage treated with atrazine declined in lowa, from $72 \%$ in 1997 to $65 \%$ in 1999 , but its usage in Missouri remained very high, with $79-95 \%$ of corn acreage treated. Metribuzin usage was primarily limited to soybeans in Missouri, with consistent annual usage of about $34000 \mathrm{~kg}$ during the study.

Herbicide Occurrence. Every herbicide and metabolite was detected in $>80 \%$ of the samples in at least 2 of the 3 years (Table 2). Atrazine was detected in $100 \%$ of samples for all 3 years, and the metabolites derived exclusively from atrazine, DEA and $\mathrm{HA}$, were the next most frequently detected compounds in the study. Both atrazine and cyanazine degradation can lead to the formation of DIA which was detected in $>90 \%$ of samples for all 3 years. Cyanazine and CYAM were detected in $>90 \%$ of samples in 1997 and 1998, but their detection frequencies were much lower in 1999 because of declining cyanazine usage. The changes in detection frequency and concentration for cyanazine (Table 2 and Figure 4) did not coincide with the reported decrease in cyanazine usage for 1998 (Figure 3). This discrepancy apparently occurred due to underreporting of cyanazine usage, and therefore, annual losses of cyanazine could not be reliably computed for 1998. Theimprovement in analytical sensitivity had the greatest effect on the detection frequency of alachlor, acetochlor, and metribuzin. From 1997 to 1998, detection frequency was increased by about two to three timesfor thesethree herbicides. Although metolachlor usage declined over the 3 years, its detection frequency increased from $85.5 \%$ in 1997 to nearly $100 \%$ in 1998 and 1999 because of the substantial improvement in its detection limit. Overall, detection frequency of the herbicides or metabolites was 
primarily affected by analytical detection limits and herbicide usage.

For all 3 years, atrazine had the highest median and maximum concentrations observed (Figure 4). Median atrazine concentrations ranged from 3.8 to $6.3 \mu \mathrm{g} / \mathrm{L}$, and it exceeded the U.S. EPA Maximum Contaminant Level (MCL) of $3 \mu \mathrm{g} / \mathrm{L}$ in $56-66 \%$ of the samples each year. Median metolachlor concentrations were consistently the second highest of the compounds studied, ranging from 0.92 to 1.5 $\mu \mathrm{g} / \mathrm{L}$, but metolachlor never exceeded the U.S. EPA Health Advisory Level (HAL) of $70 \mu \mathrm{g} / \mathrm{L}$. Median cyanazine levels were the third highest in 1997, but its levels declined 5-fold from $0.52 \mu \mathrm{g} / \mathrm{L}$ in 1998 to $0.10 \mu \mathrm{g} / \mathrm{L}$ in 1999. The HAL for cyanazine $(1.0 \mu \mathrm{g} / \mathrm{L})$ was exceeded in $47 \%$ of the samples in 1997, but by $1999<4 \%$ of the samples exceeded the HAL. CYAM concentrations were similar to the other triazine metabolites in 1997 and 1998 but decreased to a median concentration of $0.06 \mu \mathrm{g} / \mathrm{L}$ by 1999 . The other triazine metabolites (DIA, DEA, and HA) had median concentrations that ranged from $0.33 \mu \mathrm{g} / \mathrm{L}$ to $0.74 \mu \mathrm{g} / \mathrm{L}$. The median levels of acetochlor, alachlor, and metribuzin were less than the detection limit for 1997, but the lower detection limits in effect for 1998 and 1999 provided a much better representation of their concentration distributions. Alachlor had the lowest median concentration of thecompoundsstudied (0.04 $\mu \mathrm{g} / \mathrm{L}$ in 1998 and $0.03 \mu \mathrm{g} / \mathrm{L}$ in 1999), while acetochlor and metribuzin had median concentrations near $0.10 \mu \mathrm{g} / \mathrm{L}$ in 1998 and 1999. Alachlor levels exceeded its MCL of $2.0 \mu \mathrm{g} / \mathrm{L}$ in $1.0-3.7 \%$ of the samples each year, whilemetribuzin never exceeded its HAL of $100 \mu \mathrm{g} / \mathrm{L}$. Acetochlor is conditionally registered by theU.S. EPA with the requirement that its levels not exceed $2.0 \mu \mathrm{g} / \mathrm{L}$ in finished drinking water. Acetochlor exceeded this requirement in 5.2-9.0\% of the samples each year, but it is recognized that these samples do not represent finished drinking water. Overall, the factors affecting herbicide concentrations included usage, persistence in soil, stream discharge, and the hydrologic properties of the soils within the study area. The observed concentrations for this study were within the range of other regional-scale stream studies that measured these herbicides and metabolites during the critical loss period $(1,8,10,11,28)$. However, improved analytical sensitivity compared to earlier studies $(11,12,28)$ generally resulted in increased detection frequencies, even when usage of a herbicide had significantly decreased, such as alachlor and metolachlor.

Relative Herbicide Losses. To facilitate meaningful comparisons between herbicides, watersheds, and other studies, relative herbicide losses were computed as a percent of the herbicideapplied within the watershed. This approach removes the dominant influence that watershed size and herbicide usage have on absolute loads, but it relies on herbicide usage estimates of unknown accuracy (23-26). Relative herbicideloss estimates for 1996-1999 showed that the triazine herbicides had the highest losses, with peak atrazine or cyanazine losses exceeding $10 \%$ of applied in five watersheds (sites 11-15) in 1996 (Figure 5). Relative losses of metolachlor and metribuzin were slightly lower than the triazines. Median herbicide losses were as follows: $3.9 \%$ for atrazine, 2.3\% for cyanazine, $2.1 \%$ for metribuzin, $2.0 \%$ for metolachlor, $0.50 \%$ for acetochlor, and $0.33 \%$ for alachlor (Figure 5). These median losses were 2.8-40 times higher than median herbicide losses reported by Capel et al. (2) for 43 USGS National Water-Quality Assessment Program sites and for several hundred studies published in the international literature. These studies represented a variety of scales $(\leq 60$ ha to $>10000000 \mathrm{ha}$ ), soils, climates, tillage, and crops, making it the most comprehensive report to date on the topic of pesticidetransport in surfacerunoff. Thus, the region reported in this study is, overall, one of the most vulnerable to herbicide transport in the United States or worldwide.

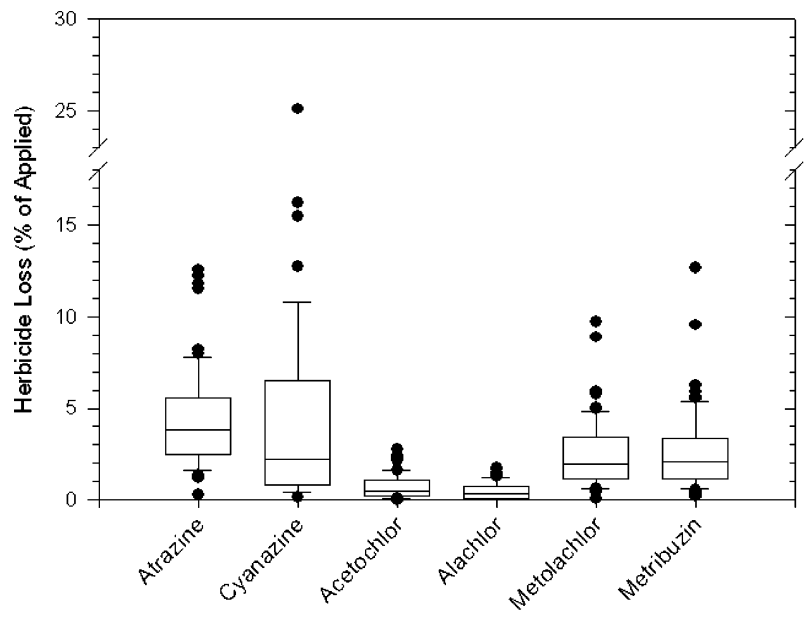

FIGURE 5. Relative herbicide loss, expressed as a percent of applied, for 1996-1999.

The relativeherbicide losses reported in Figure 5 represent conservative estimates of actual herbicide loss for three reasons: (1) metabolites were not included; (2) loss was computed for 3 months of the year; and (3) the assumed boundary conditions for extrapolation were conservative, particularly for the triazine herbicides. The best example of the importance of metabolites using our data set would be for atrazine losses, since all the major stable atrazine metabolites were measured in this study (8). When atrazine metabolites were included, with the DIA load corrected for cyanazine contribution (8), the median atrazine losses increased from $3.9 \%$ to $4.5 \%$ of applied. For the acetanilide herbicides, the contribution of metabolites to relative loss rates would be even greater than for the triazine herbicides given their more rapid soil degradation and formation of acidic metabolites that are often present in surface waters at higher levels than the parent compounds $(6,29,30)$. Although the 3-month period we defined as the critical loss period includes the majority of the annual herbicide loss, someadditional herbicidetransport occurs outsidethis time frame $(3,5,7,17)$, resulting in underestimation of losses.

Relative herbicide losses varied significantly between watersheds and over years as illustrated by relative atrazine lossesfrom 1997 to 1999 (Figure6A-C). Variability in atrazine losses between watersheds was primarily a function of watershed vulnerability to herbicide transport, as discussed below. Temporal variation in atrazine losses was affected by climate, thetiming of rainfall relative to herbicideapplication, and the interaction between these two variables. For this discussion, stream discharge of each watershed during the critical loss period was considered a surrogate for climate (i.e., total precipitation). In 1997, the lowest stream discharge was observed at all sites, and the lowest overall atrazinelosses were also observed. Thus, climate was the dominant factor affecting herbicidetransport in 1997. However, theinteraction between climate and rainfall timing becomes evident when comparing atrazine losses between 1998 and 1999. For 15 of the 20 streams (site 21 excluded), stream discharge was greatest in 1999, but only three of thesesites had their greatest atrazine losses in 1999. Furthermore, only six of 20 sites had their highest atrazine losses in the same year as their highest stream discharge. This strongly suggested that the timing of rainfall relative to herbicide application was a critical factor in the temporal variability and magnitude of herbicide transport, even at these relatively large scales.

Areal Herbicide Losses and Watershed Vulnerability. Areal herbicide loss, expressed as the sum of the mass of all herbicide and metabolite losses on a treated area basis, provides a direct measure of watershed vulnerability to 

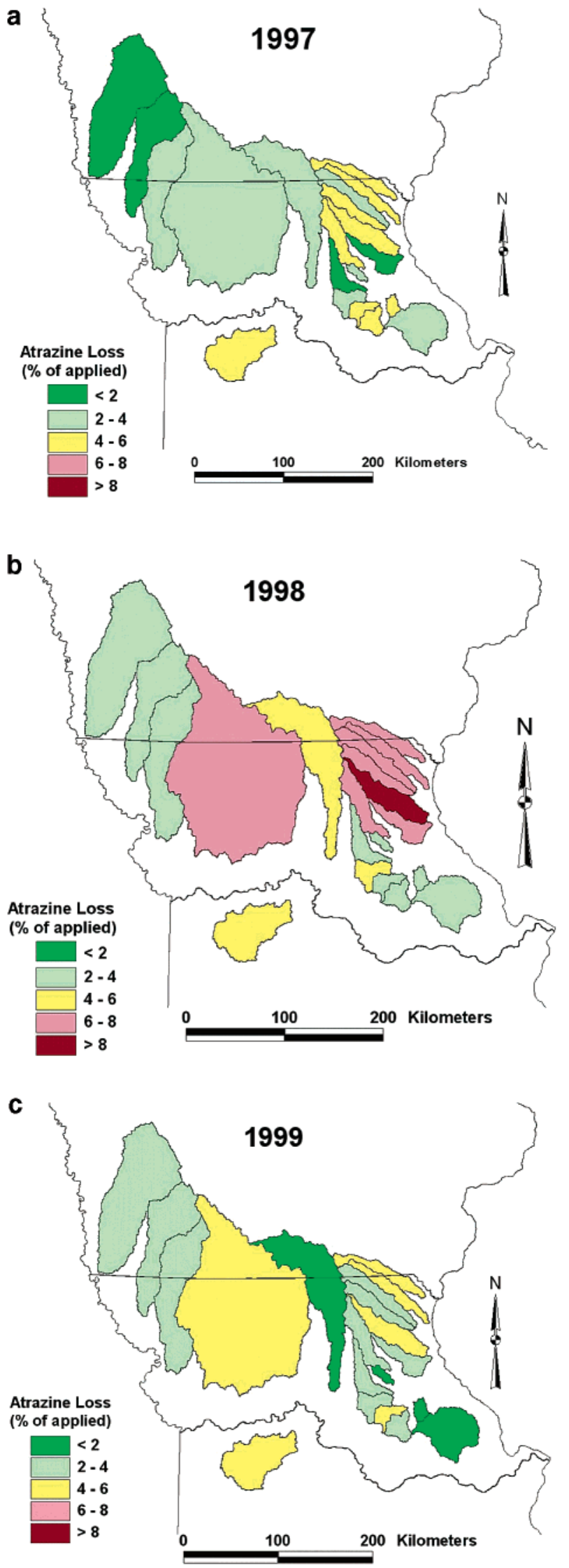

FIGURE 6. Spatial distribution of relative atrazine losses, expressed as a percent of applied: A. 1997; B. 1998; C. 1999.

herbicide transport (Figure 7). This approach to calculating relative herbicide losses, like loss as a percent of applied, also removes the influence of watershed size and herbicide

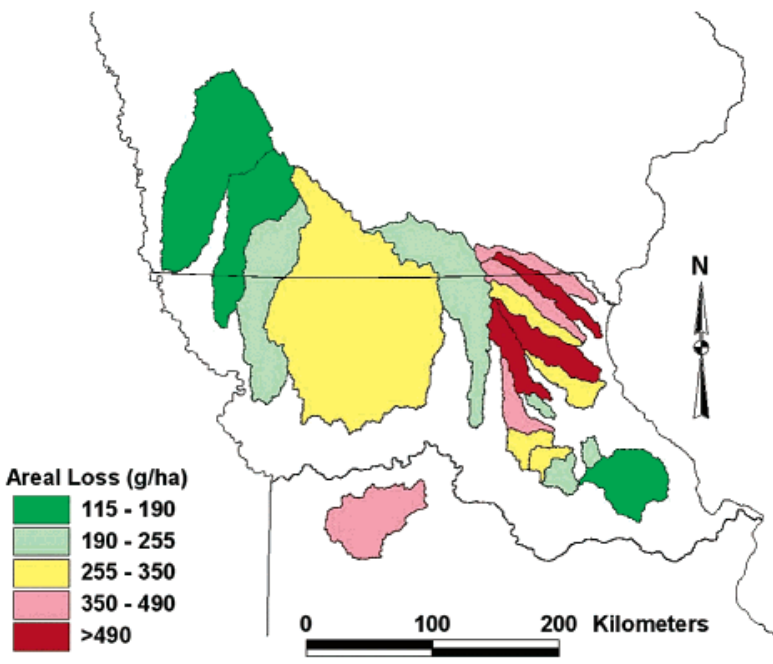

FIGURE 7. Watershed vulnerability to herbicide transport, expressed as the sum of all herbicide and metabolite losses on a treated area basis $(g / h a)$.

usage, but it has the additional advantage of using land-use data that has been verified for accuracy. Areal herbicide loss rates were the lowest in the northwestern (sites 1-3) and southeastern (sites 18-20) watersheds, and the highest loss rates occurred in several of the northeastern watersheds (sites $7-9,11,13$, and 15) and in site 6 (Figure 7). The areal loss rates generally follow the pattern of HSGC and D soils (Figure 2 ), in which herbicide loss rates tend to increase with increasing runoff potential of soils. Of the seven watersheds in which areal loss rates were $350 \mathrm{~g} / \mathrm{h}$ a or greater, six of them (sites 7-9, 11, 13, and 15) are within the Central Claypan Area (MLRA 113) or the lowa and Missouri Heavy Till Plain (MLRA 109). These six vulnerable watersheds have $>75 \%$ of their area comprised of high runoff potential soils within HSGC and D categories. Soils within these most vulnerable watersheds have naturally formed claypans or pronounced argillic horizons that restrict water percolation and increase surface runoff.

Although runoff potential was a critical factor related to herbicideloss, it did not explain all of the observed variability. In the eastern portion of the study area (sites 7-20), all the watersheds havea high percentage of their soils within HSGC and $\mathrm{D}$, but significant differences were observed in areal herbicide loss rates. For example, sites 8, 11, and 13 had the highest areal loss rates, yet other watersheds with a similar or even higher proportion of runoff prone soils, such as sites 17-20, had considerably lower loss rates. One likely factor explaining this variation was differences in topography. In general, the averageslope within these watersheds decreases going from north to south. Average slope in the northeastern watersheds is in the range of $3-5 \%$, while average slope in the southeastern watersheds is $1-3 \%$. Another potentially important factor may be the extent of no-till adoption. The use of no-till farming systems on claypan soils has been shown to increase runoff volume compared to other tillage systems (31). In addition, soil-applied herbicides arenot incorporated in no-till farming systems, leading to greater herbicide losses $(2,4,19)$. Therefore, despite beneficial reductions in soil erosion, no-till farming systems on claypan soils are much more vulnerable to herbicide losses $(19,31)$.

Contribution to the Herbicide Load in the Missouri and Mississippi Rivers. Herbicidetransport from the six Missouri River tributaries (sites 1-6) contributed a disproportionately high amount of the herbicideload to the Missouri River from 1997 to 1999 (Figure 1 and Table 3) based on computations using herbicide concentrations and stream discharge from the USGSmonitoring station at Hermann, MO (siteB in Figure 
TABLE 3. Contribution of Missouri River Tributaries to the Herbicide Load at Hermann, MO (Site B)

\begin{tabular}{|c|c|c|c|c|c|c|c|c|c|}
\hline \multirow[b]{2}{*}{ w atershed } & \multirow[b]{2}{*}{ year } & \multirow{2}{*}{$\begin{array}{l}\text { drainage area } \\
\left(\mathrm{km}^{2}\right)\end{array}$} & \multirow{2}{*}{$\begin{array}{c}\text { discharge }{ }^{a} \\
\text { (L) }\end{array}$} & \multicolumn{6}{|c|}{ kg } \\
\hline & & & & atrazine & cyanazine & acetochlor & alachlor & metolachlor & metribuzin \\
\hline \multirow[t]{4}{*}{ Missouri River Tributaries ${ }^{b}$} & 1997 & 41500 & $3.44 \mathrm{e}+12$ & 12900 & 1650 & 1580 & 159 & 4470 & 322 \\
\hline & 1998 & & $4.61 e+12$ & 33700 & 4680 & 4290 & 570 & 8100 & $C$ \\
\hline & 1999 & & $5.66 e+12$ & 29900 & 1020 & 4860 & 468 & 6730 & 684 \\
\hline & mean & & $4.57 e+12$ & 25500 & 2450 & 3580 & 399 & 6430 & 503 \\
\hline \multirow[t]{5}{*}{ Missouri River @ Hermann, MO } & 1997 & 1346000 & $3.19 e+13$ & 44600 & 6710 & 5680 & 2120 & 17990 & 703 \\
\hline & 1998 & & $2.61 e+13$ & 80800 & 8410 & 8880 & 2220 & 31100 & $c$ \\
\hline & 1999 & & $3.88 e+13$ & 77000 & 4910 & 21400 & 5380 & 41300 & 1020 \\
\hline & mean & & $3.23 e+13$ & 67500 & 6680 & 12000 & 3240 & 30130 & 862 \\
\hline & & \multicolumn{8}{|c|}{ percentage of M issouri River at Hermann, MO } \\
\hline w atershed & year & drainage area & discharge & atrazine & cyanazine & acetochlor & alachlor & metolachlor & metribuzin \\
\hline \multirow[t]{4}{*}{ Missouri River Tributaries } & 1997 & 3.1 & 10.8 & 28.9 & 24.6 & 27.8 & 7.50 & 24.8 & 45.8 \\
\hline & 1998 & & 17.7 & 41.7 & 55.6 & 48.3 & 25.7 & 26.0 & C \\
\hline & 1999 & & 14.6 & 38.8 & 20.8 & 22.7 & 8.70 & 16.3 & 67.1 \\
\hline & mean & & 14.2 & 37.8 & 36.7 & 29.8 & 12.3 & 21.3 & 58.4 \\
\hline
\end{tabular}

TABLE 4. Contribution of Mississippi River Tributaries to the Herbicide Load at Grafton, IL (Site A)

\begin{tabular}{|c|c|c|c|c|c|c|c|c|c|}
\hline \multirow[b]{2}{*}{ w atershed } & \multirow[b]{2}{*}{ year } & \multirow{2}{*}{$\begin{array}{l}\text { drainage area } \\
\left(\mathrm{km}^{2}\right)\end{array}$} & \multirow{2}{*}{$\begin{array}{c}\text { discharge }^{a} \\
\text { (L) }\end{array}$} & \multicolumn{6}{|c|}{ kg } \\
\hline & & & & atrazine & cyanazine & acetochlor & alachlor & metolachlor & metribuzin \\
\hline \multirow[t]{4}{*}{ Mississippi River Tributaries ${ }^{b}$} & 1997 & 15198 & $9.68 e+11$ & 6160 & 1780 & 472 & 150 & 2120 & 148 \\
\hline & 1998 & & $1.49 \mathrm{e}+12$ & 9940 & 1090 & 657 & 129 & 2790 & $c$ \\
\hline & 1999 & & $1.55 e+12$ & 6990 & 286 & 682 & 97 & 1890 & 172 \\
\hline & mean & & $1.34 \mathrm{e}+12$ & 7700 & 1050 & 604 & 125 & 2270 & 160 \\
\hline \multirow[t]{4}{*}{ Mississippi River @ Grafton, IL } & 1997 & 446775 & $3.47 e+13$ & 67000 & 14200 & 11400 & 1570 & 30600 & 824 \\
\hline & 1998 & & $4.30 \mathrm{e}+13$ & 128000 & 10800 & 34000 & 1720 & 60700 & $c$ \\
\hline & 1999 & & $4.68 e+13$ & 117000 & 9,350 & 33200 & 1740 & 35000 & 413 \\
\hline & mean & & $4.15 e+13$ & 104000 & 11,500 & 26200 & 1680 & 42100 & 619 \\
\hline
\end{tabular}

\begin{tabular}{cccccccccc}
\hline & & \multicolumn{5}{c}{ percentage of Mississippi River at Grafton, IL } \\
\cline { 3 - 9 } w & year & drainage area & discharge & atrazine & cyanazine & acetochlor & alachlor & metolachlor & metribuzin \\
Mississippi River Tributaries & 1997 & 3.40 & 2.79 & 9.19 & 12.5 & 4.14 & 9.55 & 6.93 & 18.0 \\
& 1998 & & 3.47 & 7.77 & 10.1 & 1.93 & 7.50 & 4.60 & $C$ \\
& 1999 & & 3.31 & 5.97 & 3.06 & 2.05 & 5.57 & 5.40 & 41.6 \\
& Mean & & 3.22 & 7.40 & 9.13 & 2.30 & 7.46 & 5.39 & 25.9
\end{tabular}

a Total stream discharge (TSD) for the critical loss period. ${ }^{b}$ Mississippi River tributaries represent the sum of sites 7-12 and $21 .{ }^{c} 1998$ data omitted.

1). Thesesixtributariesaccount for only $3.1 \%$ of the drainage area and an average of $14.2 \%$ of the stream discharge within the Missouri River basin. Annual herbicideloads from these watersheds ranged from 7.50 to $67.1 \%$ of the annual herbicide load in the Missouri River. Averaged over the 3 years, this region of the Missouri River basin contributed more than one-half of the metribuzin load, approximately one-third of theatrazine, cyanazine, and acetochlor loads, and about onefifth of the metolachlor load. Only the average alachlor load was roughly proportional to stream discharge. An important factor affecting annual variation in absolute herbicide loads for the Missouri tributaries was the total stream discharge during the critical loss period (TSD). In general, the lowest absolute herbicide loads occurred in 1997, when TSD was lowest (Table 3). In 1998 and 1999, herbicide loads ranged from 1.5 to 3.6 times that of the 1997 loads, except cyanazine in 1999, due to the greater stream discharge in thetributaries. However, relativeloads were not directly related to TSD. The highest relative loads generally occurred in 1998, when TSD was intermediate to that of 1997 and 1999. This suggested that timing of precipitation relative to herbicide application as well as precipitation distribution within thelower M issouri River basin were also important factors to the relative herbicide contribution of the Missouri tributaries.
The small area of the Missouri River basin monitored in thisstudy was obviouslya major contributor to the herbicide load within the entire basin. This is partly due to the high corn and soybean acreage, and therefore much higher herbicide inputs, in these six watersheds compared to the upper Missouri River basin (32). In addition, the Missouri tributaries are in close proximity to the NASQAN site at Hermann, MO, resultingin short transport times and minimal in-stream dissipation. However, there are still several other regions with high row cropping intensity and herbicideinputs in the lower Missouri River basin that apparently contribute a much lower proportion of the herbicide load, such as the Platte(Nebraska), Kansas, and Osage River basins. Herbicide transport from these basins may be a function of limited precipitation, rather than soil properties. Overall, the combination of high herbicide inputs, moderate to high runoff potential of the soils, high precipitation during the critical loss period, and proximity to the NASQAN monitoring site resulted in the disproportionately greater herbicide loads from these six watersheds compared to other regions within the Missouri River basin.

The Mississippi River tributaries (sites 7-12 and 21) al so contributed a disproportionately high amount of the herbicideload to the upper Mississi ppi River relativeto the USGS 
monitoring station at Grafton, IL (site A, Figure 1) (Table 4). These seven watersheds represent $3.4 \%$ of the drainage area and an average of $3.2 \%$ of the stream discharge within the upper Mississippi River basin (Table 4). Relative herbicide loads from this region accounted for 1.93 to $41.6 \%$ of the herbicideload in the upper M ississippi. Because of thegreater similarity in land-use of these watersheds to the upper Mississippi River basin, the contribution was not as disproportionate as that computed for the Missouri River basin. Metribuzin transport was the most highly disproportionate of the herbicides measured, accounting for an average of $25.9 \%$ of the load at Grafton, I L. Atrazine, cyanazine, al achlor, and metolachlor transport were also disproportionately high from this region but much less so than metribuzin. Acetochlor transport was disproportionately low relative to stream discharge when averaged over the 3 years. These data can partially be attributed to herbicide usage in the northern Missouri watersheds compared to other regions of the upper Mississippi River basin (32). For instance, metribuzin usage within the Mississippi tributaries is considerably greater and acetanilide herbicide usage, particularly acetochlor, is lower than most of the upper Mississippi River basin. Atrazine and cyanazine usage in the Mississippi tributaries was similar to other regions of the upper Mississippi River basin. The TSD of the Mississippi tributaries was generally inversely related to relative herbicideloads, but absoluteherbicideloads were not always proportional to TSD (Table 4) because of changes in herbicide usage or timing of precipitation relative to chemical application. Significant decreases in usageappeared to affect annual variation in absolute loads of cyanazine, alachlor, and metolachlor more than any other factor. Precipitation timing was the critical factor affecting absolute atrazine loads. In 1998, the major storm runoff events occurred after the primary atrazine application period, resulting in the highest atrazine loads from the Mississippi tributaries (Table 4). In 1999, the major runoff events and over $70 \%$ of the TSD occurred before the main atrazine application period, resulting in decreased atrazine loads despite the greater TSD compared to 1998.

The vulnerability of the Mississippi tributary watersheds to herbicide transport is evident when the loads of these watersheds are compared to the USGS monitoring station located at Clinton, IA (site C, Figure 1). The USGS data for Clinton, IA showed that this site accounts for $53 \%$ of the drainage area and, from 1997 to 1999, it accounted for an average of $42 \%$ of the stream discharge at Grafton, IL. Compared to the Mississippi tributaries, the Clinton, IA station drains nearly 16 times more land area and accounts for 11 times more stream discharge at Grafton, IL. Excluding metribuzin because of its higher usage in the Mississippi tributaries, the 3-year average herbicide load at Clinton, IA contributed the following to the relative herbicide load at Grafton, IL: atrazine, 8.1\%; cyanazine, $8.7 \%$; acetochlor, 16\%; alachlor, 23\%; and metolachlor, $13 \%$. Thus, the Mississippi tributaries contributed nearly equal atrazine and cyanazine loads to the upper Mississippi River basin as thearea draining to Clinton, IA (Table4). The acetanilide herbicide loads were also disproportionately lower at Clinton, IA, with relative contributions that were only 2.4-6.9 times that of the Mississippi tributaries. Furthermore, the herbicide loads computed for theM ississippi tributaries were underestimated because this area included site 21 that receives its discharge from the Mark Twain Lake reservoir. Herbicide transport in reservoir outflows typically show lower peak concentrations, but a longer period of elevated concentrations, than unregulated rivers (17). Using data from sites 13-19, output herbicide loads from the reservoir during the critical loss period ranged from only 17 to $47 \%$ of theinput load. Although some herbicide losses by degradation or sedimentation may occur during residence in the reservoir, much of the input load will eventually be discharged from the reservoir, but this will occur after the critical loss period. Hence, the estimated load of the Mississippi tributaries for the critical loss period represents a significant underestimation of the annual herbicide transport to the upper Mississippi River basin. Based on the disproportionately high contribution to the herbicide loads of the Missouri and upper Mississippi Rivers, the northern Missouri/southern Iowa region of the Corn Belt should be a priority target for implementation of BMPs to reduce herbicide transport.

\section{Acknowledgments}

We thank our river sampling volunteers with the U niversity of Missouri Extension and the County Extension offices throughoutnorthern Missouri: Ron Alexander,John Brumett, Bob Chapple, Eldon Dilworth, Charlie Ellis, Kevin Hansen, Bev Maltsberger, Vicki Schwartz, Darin Starr, and Terri Vogel. Wealso thankJoeAbsheer and Randy Spautz for conducting the herbicide analyses. Mention of specific companies, products, or trade names is madeonly to provideinformation to the reader and does not constitute endorsement by the USDA-Agricultural Research Service.

\section{Literature Cited}

(1) Blanchard, P. E.; Lerch, R. N. Environ. Sci. Technol. 2000, 34, 3315-3322.

(2) Capel, P. D.; Larson, S. J.; Winterstein, T. A. Hydrol. Process. 2001, 15, 1251-1269.

(3) Leonard, R. A. In Environmental Chemistry of Herbicides; Grover, R., Ed.; CRC Press: Boca Raton, FL, 1988; Vol. 1, pp 45-87.

(4) Wauchope, R. D. J. Environ. Qual. 1978, 7, 459-472.

(5) Donald, W. W.; Hjelmfelt, A. T.; Alberts, E. E. J. Environ. Qual. 1998, 27, 999-1009.

(6) Kalkhoff, S. J.; Kolpin, D. W.; Thurman, E. M.; Ferrer, I.; Barcelo, D. Environ. Sci. Technol. 1998, 32, 1738-1740.

(7) Lerch, R. N.; Donald, W. W.; Li, Y.-X., Alberts, E. E. Environ. Sci. Technol. 1995, 29, 2759-2768.

(8) Lerch, R. N.; Blanchard, P. E.; Thurman, E. M. Environ. Sci. Technol. 1998, 32, 40-48.

(9) Richards, P. D.; Baker, D. B.; Kramer, J. W.; Ewing, D. E. J. Great Lakes Res. 1996, 22, 414-428.

(10) Scribner, E. A.; Battaglin, W. A.; Goolsby, D. A.; Thurman, E. A. Sci. Total Environ. 2000, 248, 255-263.

(11) Thurman, E. M.; Goolsby, D. A.; Meyer, M. T.; Mills, M. S.; Pomes, M. L.; Kolpin, D. A. Environ. Sci. Technol. 1992, 26, 2440-2447.

(12) Thurman, E. M.; Goolsby, D. A.; Meyer, M. T.; Kolpin, D. W. Environ. Sci. Technol. 1991, 25, 1794-1796.

(13) Clark, G. M.; Goolsby, D. A.; Battaglin, W. A. Environ. Sci. Technol. 1999, 33, 981-986.

(14) Montgomery, J. H. AgrochemicalsDesk Reference: Environmental Data; Lewis Publishers: Chelsea, MI, 1993.

(15) Vencill, W. K. HerbicideHandbook, 8th ed.; Weed ScienceSociety of America: Lawrence, KS, 2002.

(16) Larson, S. J.; Gilliom, R. J. J. Am. Water Res. Assoc. 2001, 37, 1349-1367.

(17) Battaglin, W. A.; Goolsby, D. A. J. Am. Water Res. Assoc. 1998, 34, 1369-1390.

(18) Clausen, J. C.; Jokela, W. E.; Potter, F. I.; Willams, J. W. J. Environ. Qual. 1996, 25, 1000-1007.

(19) Alberts, E. E.; Hjelmfelt, A. T.; Donald, W. W.; Kitchen, N. R. In Proceedings of Clean Water-Clean Environment-21st Century; U.S. Department of Agriculture and American Society of Agricultural Engineering: St. Joseph, MI, 1995; pp 5-8.

(20) Kelly, V. J.; Hooper, R. P.; Aulenbach, B. T.; Janet, M. WaterResources Investigation Report 01-4255; 2001.

(21) United States Geological Survey. NASQAN Data; 1996-1999; available at http:// water.usgs.gov/nasqan/data.

(22) United States Department of Agriculture-National Agricultural Statistics Service. Crops: County and District Data; available at http:// www. nass.usda.gov/ipedb.

(23) Agricultural Chemical Usage, 1996 Field Crop Summary; Report Ag Ch 1(97); United States Department of Agriculture-National Agricultural Statistics Service and Economics Research Service: Washington, DC, 1997; 100 pp.

(24) Agricultural Chemical U sage, 1997 Field Crop Summary; Report Ag Ch 1(98); United States Department of Agriculture-National 
Agricultural Statistics Service and Economics Research Service: Washington, DC, 1998; $100 \mathrm{pp}$.

(25) Agricultural Chemical Usage, 1998Field Crop Summary; Report AgCh 1(99); United States Department of Agriculture-National Agricultural Statistics Service and Economics Research Service: Washington, DC, 1999; $141 \mathrm{pp}$.

(26) Agricultural Chemical Usage, 1999Field Crop Summary; Report AgCh 1(00)a; United States Department of Agriculture-National Agricultural Statistics Service and Economics Research Service: Washington, DC, 2000; 120 pp.

(27) United States Department of Agriculture. USDA Agricultural Handbook 296; 1981.

(28) Battaglin, W. A.; Goolsby, D. A. Environ. Sci. Technol. 1999, 33, 2917-2925
(29) Phillips, P. J.; Wall, G. R.; Thurman, E. M.; Eckhardt, D. A.; Vanhoesen, J. Environ. Sci. Technol. 1999, 33, 3531-3537.

(30) Thurman, E. M.; Goolsby, D. A.; Aga, D. S.; Pomes, M. L.; Meyer, M. T. Environ. Sci. Technol. 1996, 30, 569-574.

(31) Ghidey, F.; Alberts, E. E. J. Soil Water Conserv. 1998, 53, 64-70

(32) United States Geological Survey. Annual Herbicide Use Maps; 1998; available at http://ca.water.usgs.gov/pnsp/use92/index.html.

Received for review April 15, 2003. Revised manuscript received August 14, 2003. Accepted August 20, 2003.

ES030431S 